\title{
Cyanophage Propagation in the Freshwater Cyanobacterium Phormidium Is Constrained by Phosphorus Limitation and Enhanced by Elevated $p \mathrm{CO}_{2}$
}

\author{
Kai Cheng ${ }^{1,2 *}$, Thijs Frenken ${ }^{2}$, Corina P. D. Brussaard ${ }^{3}$ and Dedmer B. Van de Waal ${ }^{2}$ \\ ${ }^{1}$ Hubei Key Laboratory of Ecological Restoration for River-Lakes and Algal Utilization, College of Resources \\ and Environmental Engineering, Hubei University of Technology, Wuhan, China, ${ }^{2}$ Department of Aquatic Ecology, \\ Netherlands Institute of Ecology, Wageningen, Netherlands, ${ }^{3}$ Department of Marine Microbiology and Biogeochemistry, \\ Royal Netherlands Institute for Sea Research and University of Utrecht, Texel, Netherlands
}

OPEN ACCESS

Edited by:

Curtis A. Suttle

University of British Columbia,

Canada

Reviewed by:

Sigitas Šulčius,

Linnaeus University, Sweden

Caroline Chenard,

Nanyang Technological University,

Singapore

Beatriz Díez,

Pontificia Universidad Católica

de Chile, Chile

${ }^{*}$ Correspondence:

Kai Cheng

chengkaicn@163.com

Specialty section:

This article was submitted to

Aquatic Microbiology,

a section of the journal

Frontiers in Microbiology

Received: 30 November 2018

Accepted: 11 March 2019

Published: 29 March 2019

Citation:

Cheng K, Frenken T,

Brussaard CPD and Van de Waal DB

(2019) Cyanophage Propagation

in the Freshwater Cyanobacterium

Phormidium Is Constrained by Phosphorus Limitation and Enhanced by Elevated $\mathrm{pCO}_{2}$.

Front. Microbiol. 10:617. doi: 10.3389/fmicb.2019.00617
Intensification of human activities has led to changes in the availabilities of $\mathrm{CO}_{2}$ and nutrients in freshwater ecosystems, which may greatly alter the physiological status of phytoplankton. Viruses require hosts for their reproduction and shifts in phytoplankton host physiology through global environmental change may thus affect viral infections as well. Various studies have investigated the impacts of single environmental factors on phytoplankton virus propagation, yet little is known about the impacts of multiple factors, particularly in freshwater systems. We therefore tested the combined effects of phosphorus limitation and elevated $\mathrm{pCO}_{2}$ on the propagation of a cyanophage infecting a freshwater cyanobacterium. To this end, we cultured Phormidium in P-limited chemostats under ambient (400 $\mu \mathrm{atm})$ and elevated $(800 \mu \mathrm{atm}) \mathrm{pCO}_{2}$ at growth rates of $0.6,0.3$, and $0.05 d^{-1}$. Host C:P ratios generally increased with strengthened P-limitation and with elevated $p \mathrm{CO}_{2}$. Upon host steady state conditions, virus growth characteristics were obtained in separate infection assays where hosts were infected by the double-stranded DNA cyanophage PP. Severe P-limitation (host growth $0.05 \mathrm{~d}^{-1}$ ) led to a $85 \%$ decrease in cyanophage production rate and a $73 \%$ decrease in burst size compared to the $0.6 \mathrm{~d}^{-1}$ grown P-limited cultures. Elevated $\mathrm{pCO}_{2}$ induced a $96 \%$ increase in cyanophage production rate and a $57 \%$ increase in burst size, as well as an $85 \%$ shorter latent period as compared to ambient $\mathrm{pCO}_{2}$ at the different host growth rates. In addition, elevated $p \mathrm{CO}_{2}$ caused a decrease in the plaquing efficiency and an increase in the abortion percentage for the $0.05 \mathrm{~d}^{-1}$ P-limited treatment, while the plaquing efficiency increased for the $0.6 \mathrm{~d}^{-1} \mathrm{P}$-limited cultures. Together, our results demonstrate interactive effects of elevated $\mathrm{pCO}_{2}$ and $\mathrm{P}$-limitation on cyanophage propagation, and show that viral propagation is generally constrained by P-limitation but enhanced with elevated $\mathrm{pCO}_{2}$. Our findings indicate that global change will likely have a severe impact on virus growth characteristics and thereby on the control of cyanobacterial hosts in freshwater ecosystems.

Keywords: climate change, pathogen, cyanobacterial virus, adsorption, one step growth curve, EOP, abortive infection, freshwater 


\section{INTRODUCTION}

Phytoplankton plays a key role in the structure and functioning of aquatic ecosystems. They contribute to approximately half of the biosphere's net primary production and $\mathrm{CO}_{2}$ fixation (Field et al., 1998). Since the industrial revolution, nutrient loading has been progressively increasing, which stimulates phytoplankton growth in many freshwater lakes (Battarbee et al., 2012; Schindler, 2012). Particularly, eutrophication has been associated with the development of harmful cyanobacterial blooms, posing an eminent threat to water quality (O'Neil et al., 2012; Paerl and Otten, 2013). Phormidium is a globally widespread genus of filamentous cyanobacteria, distributed from oligotrophic to eutrophic freshwater lakes (Fujimoto et al., 1997; Singh et al., 2014) with increased frequency and intensity over the last decade (McAllister et al., 2016). Although best known for forming benthic mats (McAllister et al., 2016), it can also form planktonic blooms (Srivastava et al., 2015; Iwayama et al., 2017). Various Phormidium species are known to produce toxins, causing their proliferations to be a risk for human and ecosystem health (Chaturvedi et al., 2015; Sinang et al., 2015; McAllister et al., 2016; Wood et al., 2017).

As a result of ongoing fossil fuel combustion, atmospheric $\mathrm{CO}_{2}$ partial pressure $\left(p \mathrm{CO}_{2}\right)$ is predicted to nearly double by the end of this century (Stocker et al., 2013; Friedlingstein et al., 2014). Elevated $p \mathrm{CO}_{2}$ may affect phytoplankton primary production (Shi et al., 2017), growth rates (Boatman et al., 2017), cell size (Finkel et al., 2010; Mou et al., 2017) and can lead to enhanced cellular carbon to nutrient ratios (Fu et al., 2007; Van de Waal et al., 2010; Garcia et al., 2011). Increased $p \mathrm{CO}_{2}$, together with other greenhouse gasses, has caused an increase in the global mean temperature and led to warming of the upper water layers of lakes and oceans, which may in turn enhance thermal stratification (Stocker et al., 2013). Subsequently, the supply of nutrients from deeper waters to the surface layer will decrease and thereby suppress primary production (Behrenfeld et al., 2006; Boyce et al., 2011). Freshwater ecosystems, including those dominated by cyanobacteria, may experience nitrogen (N) or phosphorus (P) limitation (Carpenter et al., 1996; Elser et al., 2007; Paerl et al., 2016). Besides a reduced growth rate and biomass build-up (Xu et al., 2010), limitation by nutrients may also lead to an increase in cellular carbon to nutrient stoichiometry (Sterner and Elser, 2002). Such an increase in carbon to nutrient ratios under nutrient limitation can be further enhanced by elevated $p \mathrm{CO}_{2}$ (Verspagen et al., 2014a), causing a stronger elemental imbalance with potential consequences for higher trophic levels (Sterner and Elser, 2002; Van de Waal et al., 2010).

Population dynamics of cyanobacteria does not only depend on growth related factors such as nutrient availability, but also on mortality related factors like grazers and pathogens. Viruses are highly abundant pathogens and are widely distributed throughout aquatic systems (Suttle, 2007; Wigington et al., 2016). Through lytic infection-induced host lysis, viruses stimulate the microbial loop and are key drivers of nutrient regeneration and element cycling (Gobler et al., 1997; Brussaard et al., 2005a,b;
Jover et al., 2014; Mojica et al., 2016). Viruses can strongly control host populations and can be responsible for bloom demise (Brussaard, 2004b; Jenkins and Hayes, 2006; Tijdens et al., 2008; Steenhauer et al., 2016). To date, numerous cyanophages infecting the freshwater cyanobacterium Phormidium have been isolated (Safferman and Morris, 1963; Cheng et al., 2007; Liu et al., 2007, 2008), yet little is known about their responses to global change factors.

Viruses rely on their host's metabolism for reproduction, and their infection success is thus closely linked to the physiological status of the host (Mojica and Brussaard, 2014). Global climate change related alterations in phytoplankton host physiology has been shown to impact virus-host interactions, i.e., viral latent period, burst size and viral infectivity (Wilson et al., 1996; Carreira et al., 2013; Maat and Brussaard, 2016; Maat et al., 2016a,b; Steenhauer et al., 2016). Earlier studies have reported the effects of either elevated $p \mathrm{CO}_{2}$ or nutrient depletion on the interactions between filamentous cyanobacteria and their cyanophages (Zhou et al., 2015; Shang et al., 2016; Cheng et al., 2017). There are no reports, however, on the combined effects of both factors on filamentous cyanobacterial hosts and their cyanophage infections. Moreover, earlier studies on cyanophages were performed using batch-cultured hosts (Shang et al., 2016), and thus effects could indirectly result from changes in host growth rate and/or growth phase.

To this end, we used chemostats to expose Phormidium to a combination of three different $\mathrm{P}$ supply rates reaching different extents of P-limitation, both at ambient and elevated $p \mathrm{CO}_{2}$. In chemostats at steady state, host growth rate is controlled by the dilution rate, and cultures can be kept in a P-limited, rather than P-depleted growth phase. During steady state, subsamples of Phormidium from the chemostats were exposed to infection with the cyanophage PP (Cheng et al., 2017). This allowed the assessment of key infection characteristics, such as adsorption, efficiency of plaquing (EOP; the relative proportion of cyanophages forming plaques), abortion percentage (the relative portion of adsorbed cyanophages not forming plaques), latent period, infective production rate (the maximum rate of increase in infections) and infective burst size, in relation to the host response to elevated $p \mathrm{CO}_{2}$ and P-limitation.

\section{MATERIALS AND METHODS}

\section{Experimental Setup}

A schematic overview of the experiment set-up is provided in Figure 1. In short, the cyanobacterium Phormidium was cultured in six chemostats that received a BG-11 medium with reduced $\mathrm{PO}_{4}{ }^{3-}$ concentrations (i.e., $4.3 \%$ of BG-11, see also below) at dilution rates of $0.6,0.3$, and $0.05 \mathrm{~d}^{-1}$, at ambient $(400 \mu \mathrm{atm})$ and elevated $(800 \mu \mathrm{atm}) p \mathrm{CO}_{2}$. The applied dilution rates resembled 83,50 , and $17 \%$ of the maximum growth rate of Phormidium. At steady state (when the host cultures were fully conditioned to the different treatments), subsamples were taken to perform triplicate virus infection assays. Steady state was reached at day 40 and experiments lasted until day 59. 


\section{Phormidium}

\section{Cyanophage PP}

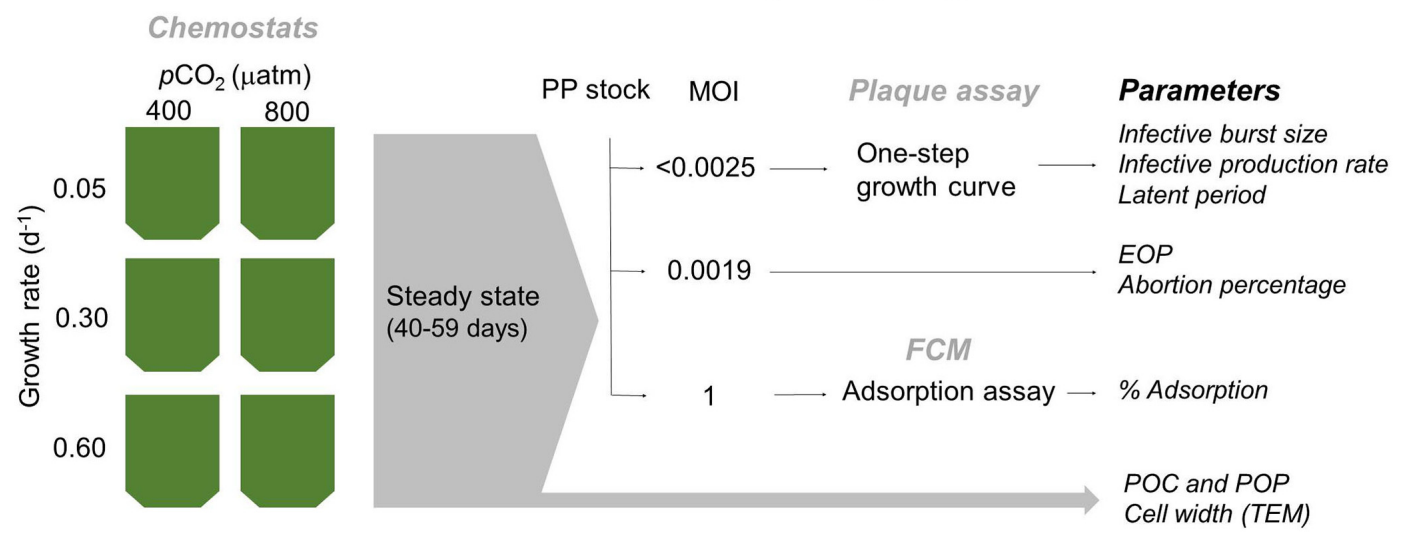

FIGURE 1 | Schematic overview of the experimental setup and sampled parameters. At steady state conditions (after 40-59 days), chemostats were sampled for specific parameters (gray arrow), and for various infection assays (black arrows). MOI, multiplicity of infection; EOP, efficiency of plaquing; FCM, flow cytometry; POC and POP, particulate organic carbon and phosphorus, respectively; TEM, transmission electron microscopy.

\section{Cultivation of Phormidium}

Phormidium sp. was isolated in 2008 from Donghu lake (i.e., East Lake, Wuhan, China) and was identified by its partial $16 \mathrm{~S}$ rDNA sequence (Zhou et al., 2010). Cultures (unialgal) were maintained in $100 \mathrm{~mL}$ Erlenmeyer flasks at $30-40 \mu \mathrm{mol}$ photons $\mathrm{m}^{-2} \mathrm{~s}^{-1}$ (14:10 h light:dark cycle) and $24^{\circ} \mathrm{C}$. Batch monocultures were diluted 1:10 (v:v) weekly using sterile filtered $(0.22 \mu \mathrm{m}$ polyethersulfone membrane filter; Sartopore Midicap; Sartorius A.G., Göttingen, Germany) standard BG-11 medium (Andersen, 2005) to keep the cells exponentially growing (maximum growth rate of about $0.72 \mathrm{~d}^{-1}$ ). Prior to transfer to the chemostats, Phormidium was acclimated to BG-11 medium with reduced $\mathrm{PO}_{4}{ }^{3-}$ concentrations $\left(10 \mu \mathrm{M} \mathrm{K}_{2} \mathrm{HPO}_{4}\right.$, i.e., $4.3 \%$ $\mathrm{P}$ of standard BG-11 medium) for at least 14 days (i.e., about 14 generations).

The chemostat cultures consisted of flat panel $1.7 \mathrm{~L}$ glass vessels (Huisman et al., 2002) at a light-dark cycle of 16:8 h. The average light intensity was calculated as $\left(I_{\text {in }}-I_{\text {out }}\right) /\left(\ln I_{\text {in }}-\ln \right.$ $I_{\text {out }}$ ) (Huisman et al., 2002), where $I_{\text {in }}$ is the average incoming light (PL-L 24W/840/4p, Philips, Netherlands) intensity, and $I_{\text {out }}$ was the average outgoing light intensity. The average (nonlimiting) light intensity was $68 \mu \mathrm{mol}$ photons $\mathrm{m}^{-2} \mathrm{~s}^{-1}$ at day 1 . The higher irradiance and longer light period compared to pre-culturing was chosen to avoid light limitation during the experiments. Temperature was kept constant at $25 \pm 1^{\circ} \mathrm{C}$ by means of a cooling finger, and aeration ensured homogeneous mixing. Cultures were supplied with compressed air at a fixed flow rate of $20 \mathrm{~L} \mathrm{~h}^{-1}$, with a $p \mathrm{CO}_{2}$ of $400 \mu \mathrm{atm}$ in the control conditions and $800 \mu \mathrm{atm}$ in the elevated $p \mathrm{CO}_{2}$ conditions. The $p \mathrm{CO}_{2}$ were confirmed by using an Omniport 30 multifunctional handheld $\mathrm{CO}_{2}$ meter (E+E Elektronik $\mathrm{GmbH}$, Engerwitzdorf, Austria).

At steady state during days $40-59$, subsamples were taken for particulate organic carbon (POC), particulate organic phosphorus (POP) and dissolved inorganic phosphate analysis. Transmission electron microscopy (TEM) pictures were taken to monitor changes in the morphology of Phormidium cells. The dissolved inorganic phosphate concentrations at steady state were below the detection limit $(<0.01 \mu \mathrm{M})$ for all treatments. For analyses of POC, $10 \mathrm{~mL}$ of cell suspension was filtered through a demi-water pre-washed $25 \mathrm{~mm}$ GF/F filter (Whatman ${ }^{\mathrm{TM}}$, Maidstone, United Kingdom) (Frenken et al., 2016), which was subsequently dried overnight at $60^{\circ} \mathrm{C}$ and stored in a desiccator. Most of the heterotrophic bacteria (sampled and counted using the protocol by Marie et al. (2001) in combination with a Beckman Coulter MoFlo Legacy Cell Sorter flow cytometer) in the Phormidium cultures passed through the nominal 0.7 $\mu \mathrm{m}$ pore-size GF/F filters and so we consider the POC and POP results to mainly reflect the cyanobacterial elemental composition. The filtrate was used to measure the phosphate concentration with a QuAAtro segmented flow analyzer (Seal Analytical Incorporated, Beun de Ronde, Abcoude, Netherlands). For POC analyses, a subsample of $14.5 \%$ was taken from each filter by perforation. The acquired punches were then folded in a tin cup and POC was analyzed on a Flash EA 1112 NC analyzer (Interscience, Milan, Italy). POP was determined by first incinerating the remaining $85.5 \%$ subsample for $30 \mathrm{~min}$ at $500^{\circ} \mathrm{C}$, followed by a $2 \%$ persulfate digestion step in the autoclave for $30 \mathrm{~min}$ at $121^{\circ} \mathrm{C}$. Subsequently, the digested samples were analyzed for $\mathrm{PO}_{4}{ }^{3-}$ using a QuAAtro segmented flow analyzer (Seal Analytical Incorporated, Beun de Ronde, Abcoude, Netherlands). Reported POC, POP and cellular C:P ratios indicate means of the experimental period $(n=3)$, during which all virus infection assays were performed.

To inspect any morphological changes in the cyanobacteria in response to different $\mathrm{CO}_{2}$ and $\mathrm{P}$ supply rates, TEM photographs were taken for every treatment. To this end, $20 \mathrm{~mL}$ of Phormidium was concentrated to $0.5 \mathrm{~mL}$ by centrifugation at $8,000 \times \mathrm{g}$, at $4^{\circ} \mathrm{C}$ for $90 \mathrm{~min}$ on day 59 , after which $0.2 \mathrm{~mL}$ glutaraldehyde $(2.5 \%)$ was immediately added to the pellet for fixation. Thereafter, additional fixation was done by immersing the sample in $1 \%$ osmic acid for $4 \mathrm{~h}$, after which the sample was concentrated by centrifugation at $3,000 \times g$ for $5 \mathrm{~min}$ at $4^{\circ} \mathrm{C}$ and $0.5 \mathrm{~mL}$ PBS was added to the precipitate 
before washing. Centrifugation and washing were repeated three times. Dehydration was done by immersing the sample in alcohol solutions from 50 to $100 \%$ by a gradual increasing gradient with steps of $10 \%$. Samples were then embedded in Spurr resin (ERL-4206). Ultra-thin sections were made by a UC7 ultramicrotome (Leica, Germany) and stained with uranyl acetate and lead citrate. A Tecnai G20 TWIN TEM (FEI, United States) was used to measure the cyanobacterial cell width at a magnification of $1700 \times$ to $5000 \times$.

\section{Culturing of Cyanophage PP}

The cyanophage PP, named after the respective first letter of its two known hosts (Plectonema boryanum IU 594 and Phormidium foveolarum IU 427), was isolated in 2001 from a eutrophic freshwater pond in Wuhan, China (Zhao et al., 2002; Cheng et al., 2007). It is characterized as a short-tailed, icosahedral-shaped, double-stranded DNA virus (Cheng et al., 2007). To prepare the PP stock [with a titer of $1.07 \times 10^{8}$ plaque forming units (PFU) $\mathrm{mL}^{-1}$ ] for the infection assays, $10 \mathrm{~mL}$ stored PP lysate was inoculated with $100 \mathrm{~mL}$ batch cultured Phormidium at exponential growth, using a multiplicity of infection (MOI, defined as the ratio of the titer of cyanophage PP to the cell density of Phormidium) of 1 . The mixture was cultured in the same condition as the batch culture of Phormidium for 2 days. Subsequently, for the preservation of cyanophage stock, $11 \mathrm{~mL}$ chloroform was added to the mixture followed by rigorous manual shaking for $1 \mathrm{~min}$ (Fox et al., 1976). Then the mixture was placed at $4^{\circ} \mathrm{C}$ without shaking for $1 \mathrm{~h}$ before $20 \mathrm{~mL}$ of $100 \mathrm{~mL}$ supernatant was carefully pipetted out (Fox et al., 1976) and stored at $4^{\circ} \mathrm{C}$ (Cheng et al., 2007). This PP stock was diluted for more than 100 times for the infection assays. To assess the titer of this stock, it was serial diluted by standard BG-11 medium and a plaque assay was performed (Suttle, 1993) up to 1 week prior to the infection assays. For the plaque assay, $12 \mathrm{~mL}$ solid standard BG-11 media with 1\% agar (Sigma, A1296, St. Louis, $\mathrm{MO}$, United States) was plated in a $90 \mathrm{~mm}$ diameter petri-dish to form the bottom layer. Then $0.1 \mathrm{~mL}$ of serial diluted stock sample was mixed with $1.9 \mathrm{~mL}$ of batch cultured Phormidium cells (with a density of 2.0-6.0 $\times 10^{7}$ cells $\mathrm{mL}^{-1}$ ) in standard BG-11 media. Cultures were rapidly plated in the above mentioned petri-dish with $2 \mathrm{~mL}$ pre-heated $65^{\circ} \mathrm{C}$ standard BG-11 media with $1 \%$ agar. The plates were subsequently incubated for 2-3 days under the same culture conditions as Phormidium batch cultures, after which plaques were counted.

\section{Infection Assays}

All virus infection assays, i.e., the adsorption assay, viral growth curve, EOP, and abortion percentage assays, were performed during steady state between days 50 and 59 of the chemostat experiments. During this period, culture material for the assays was sampled from the chemostats approximately $3 \mathrm{~h}$ after the start of the light period. Average light intensities in the chemostats were 52-58 $\mu \mathrm{mol}$ photons $\mathrm{m}^{-2} \mathrm{~s}^{-1}$ (nonlimiting light condition) during the period infection assays were performed (from day 50 to 59). To assess the various cyanophage characteristics, samples were taken for short term
$(<8 \mathrm{~h})$ infection assays with cyanophage $\mathrm{PP}$, which were all performed in triplicate.

To homogenize Phormidium host cultures and to separate filaments, $10 \mathrm{~mL}$ of sample was pipetted up and down with $5 \mathrm{~mL}$ pipettes for at least 10 times, after which the culture was sieved over a $30 \mu \mathrm{m}$ nylon mesh. The filtrate was concentrated by centrifugation at $16,000 \times g$ for $1 \mathrm{~h}$ at $25^{\circ} \mathrm{C}$, after which the cyanobacterial pellet was re-suspended in $10 \mathrm{~mL}$ low P containing BG-11 medium. Cell abundances were then calculated from trichome length measurements, determined using a hemocytometer (with a volume of $0.1 \mathrm{~mm}^{3}$ ) on an inverted microscope (DMI 4000B, Leica Microsystems CMS $\mathrm{GmbH}$, Mannheim, Germany). First, the average cell length (A) was assessed by dividing the total length of 10 randomly selected trichomes with their cell numbers. Afterward, the total length of all trichomes in at least 10 counting chambers were measured for each sample, and the average total length of trichomes per counting chamber (L) was calculated. The average cell density (per $\mathrm{mL}$ ) was subsequently calculated as $\mathrm{L} / \mathrm{A} \times 10^{4}$. After counting, all cultures were then further diluted in low $\mathrm{P}$ containing medium to equalize host cell density to $1 \times 10^{6}$ cells $\mathrm{mL}^{-1}$.

\section{Adsorption Assay, Efficiency of Plaquing and Abortion Percentage}

For the adsorption assay, $4 \mathrm{~mL}$ of the diluted Phormidium host culture was mixed with the cyanophage PP stock at MOI of 1 and grown at $p \mathrm{CO}_{2}$ and non-limiting light conditions comparable to the chemostats (i.e., $60 \mu \mathrm{mol}$ photons $\mathrm{m}^{-2} \mathrm{~s}^{-1}$ ). Samples of $0.8 \mathrm{~mL}$ were taken at different time points $(0,30$, and $60 \mathrm{~min})$. Next, these samples were centrifuged at $16,000 \times g$ at $4^{\circ} \mathrm{C}$ for $25 \mathrm{~min}$ of which $400 \mu \mathrm{L}$ supernatant was fixed with 25\%-glutaraldehyde (Merck, Darmstadt, Germany) to a final concentration of $0.5 \%$, where after the sample was stored in the dark at $4^{\circ} \mathrm{C}$ and analyzed within $24 \mathrm{~h}$. Viruses were sampled and enumerated using flow cytometry according to the protocol by Brussaard (2004a) with modification by Mojica et al. (2014). In short, samples were diluted in Tris-EDTA buffer ( $\mathrm{pH} 8.2$; Mojica et al., 2014) and stained with SYBR Green I (final concentration of $5 \times 10^{-5}$ of commercial stock, Sigma-Aldrich, St. Louis, MO, United States) for $10 \mathrm{~min}$ in the dark at $80^{\circ} \mathrm{C}$. Samples were analyzed on a MoFlo Legacy Cell Sorter with a $488 \mathrm{~nm}$ argon laser and the trigger on green fluorescence (of the nucleic acid-specific staining by SYBR Green I). The adsorption ratio at any time point $t$ was calculated as $100 \%-\left(V_{\mathrm{t}} / V_{0}\right)$, where $V_{0}$ and $V_{\mathrm{t}}$ are the virus abundances at time point 0 and $t$, respectively.

To determine the EOP and the abortion percentage, the cyanophage PP stock was mixed with $4 \mathrm{~mL}$ diluted host cell cultures $\left(0.7 \times 10^{6}\right.$ cells $\left.\mathrm{mL}^{-1}\right)$ to a sufficient low final concentration reaching $1,300 \mathrm{PFU} \mathrm{mL} \mathrm{mL}^{-1}$ (defined as $P_{0}$, determined by plaque assay, i.e., at MOI of 0.0019). This low concentration was used to avoid multiple adsorption of phages adsorbed to a single trichome. The mixed samples were then incubated in the light (60 $\mu$ mol photons $\mathrm{m}^{-2} \mathrm{~s}^{-1}$ ) for $15 \mathrm{~min}$ after which $2 \mathrm{~mL}$ was subsampled and centrifuged at $16,000 \times g$ at $25^{\circ} \mathrm{C}$ for $90 \mathrm{~min}$. Then, the titer in both the supernatant and pellet were 
determined by plaque assays (Suttle, 1993), providing $P_{1}$ and $P_{2}$, respectively. The EOP was calculated as $P_{2} / P_{0}$, and the abortion percentage was calculated as $100 \%-P_{2} /\left(P_{0}-P_{1}\right)$.

\section{Latent Period, Production and Infective Burst Size}

For the one step growth curve, cyanophage PP stock was added to the above mentioned filtrate at a low MOI of $0.00025-0.0025$ (i.e.,

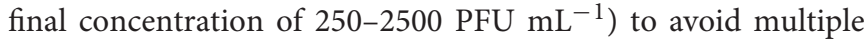
infections to a single trichome after a first round of lysis (Cheng et al., 2017). After $10 \mathrm{~min}$ of incubation in the light $(60 \mu \mathrm{mol}$ photons $\mathrm{m}^{-2} \mathrm{~s}^{-1}$ ) to allow adsorption, $4 \mathrm{~mL}$ mixtures were centrifuged at $16,000 \times g$ for $25 \mathrm{~min}$ at $25^{\circ} \mathrm{C}$. The pellets were collected, washed twice in low $\mathrm{P}$ containing BG-11 medium, and then resuspended in $25 \mathrm{~mL}$ of low $\mathrm{P}$ containing BG-11 medium and incubated at $p \mathrm{CO}_{2}$ and light conditions similar to the chemostat conditions. Since the released new cyanophages may rapidly adsorb to the nearby hosts, cultures were shaken on an INFORS Multitron incubator shaker (INFORS HT, Switzerland) for $6 \mathrm{~h}$ at $40 \mathrm{rpm}$ to disperse the new cyanophages before they attached to nearby hosts (thereby preventing multiple infections of a single trichome). Subsequently, to make sure 5-150 plaques can be formed in a single plate, 0.1 and $1 \mathrm{~mL}$ of subsamples were taken from the resuspended cultures every hour for a period of up to $8 \mathrm{~h}$, and mixed with 1.9 or $1 \mathrm{~mL}$ of batch cultured Phormidium cells in standard BG-11 medium, respectively (equaling a total of $2 \mathrm{~mL}$ ). Then, the cyanophage titers of the mixture were determined using the plaque assay method (Suttle, 1993) as mentioned above. To normalize the data, titers at each time point were divided by the titer at $t_{0}$ to get the relative titers. To determine the latent period, one step growth curves were constructed directly by using those relative titers, and the end of latent period was determined as the time point when the average relative titer increased to higher than 1 . To determine the average infective burst size (i.e., the number of new infections released by a single infected host cell) and the infective production rate (i.e., the maximum rate of increase in infections), a modified Gompertz sigmoid growth function (Zwietering et al., 1990) was constructed based on the relative titer:

$$
y=B \times \exp \left(-\exp \left(\frac{r_{\mathrm{m}} \times e}{B}(\lambda-t)+1\right)\right)+1
$$

where $y$ indicates the titer at time $t, B$ the infective burst size, $r_{\mathrm{m}}$ the infective production rate, $e$ the mathematical constant (i.e., 2.718), and $\lambda$ is the point on the $x$-axis where the slope from the maximum increase meets $y=1$. We note that the infective burst size and infective production rate are based on plaque forming units, and thus represent the maximum number of infections after one lytic cycle and the maximum increase of infections, respectively. Fits were performed using least square fitting with the Microsoft Excel 2013 Solver GRG non-linear fitting procedure with a multiStart population size of 200 .

\section{Statistical Analysis}

The virus infection data were Ln- or square-root-transformed to improve normality and equality of variance, which were confirmed using the Kolmogorov-Smirnov test and Levene's test, respectively. Significance of differences between treatments were tested using an one-way ANOVA, followed by post hoc comparison of the means using Fisher's Least Significant Difference (LSD) test if the data was homoscedastic, or using the Games-Howell test if the data were not homoscedastic. The interaction effect between the $\mathrm{CO}_{2}$ treatments and host growth rates was tested using a two-way ANOVA. Correlation analysis was performed by using a Spearman's test. All statistics were performing with SPSS Statistics 17.0 (IBM Inc., United States).

\section{RESULTS}

At steady state, Phormidium showed lowest POC concentrations at the highest growth rate $\left(0.6 \mathrm{~d}^{-1}\right)$ at both $p \mathrm{CO}_{2}$ levels (Table 1). Similarly, POP concentrations were lowest at the highest growth rate, and showed a distinct increase with decreasing growth rate both under ambient and elevated $\mathrm{pCO}_{2}$ (Table 1). Average C:P ratios generally increased with elevated $p \mathrm{CO}_{2}$ across growth rates, with a strongest effect at the lowest growth rate (Table 1). There was furthermore a significant interaction between growth rate and elevated $p \mathrm{CO}_{2}(P<0.05$, Table 2$)$. For the elevated $p \mathrm{CO}_{2}$ treatment, the average width of the cyanobacterial cells at the lowest growth rate was $8-15 \%$ larger than for intermediate and highest growth rate (Figure 2). For the ambient $p \mathrm{CO}_{2}$ treatment, the cell width was $60-67 \%$ higher at the low growth rate as compared to the intermediate and highest growth rates.

TABLE 1 | Overview of host biomass and stoichiometry, with particulate organic carbon (POC) and phosphorus (POP) and cellular C:P ratios.

\begin{tabular}{|c|c|c|c|c|c|c|c|}
\hline \multicolumn{2}{|c|}{ Treatments } & \multicolumn{2}{|c|}{ POC ( $\mu \mathrm{M})$} & \multicolumn{2}{|c|}{ POP $(\mu \mathrm{M})$} & \multicolumn{2}{|c|}{ Cellular C:P } \\
\hline $\begin{array}{l}\mathrm{pCO}_{2} \\
\text { ( } \mu \text { atm) }\end{array}$ & $\begin{array}{c}\text { Growth } \\
\text { rate }\left(\mathbf{d}^{-1}\right)\end{array}$ & Mean & SD & Mean & SD & Mean & SD \\
\hline 400 & 0.05 & 1567 & 580 & 9.1 & 3.8 & 173 & 17 \\
\hline 800 & 0.05 & 2724 & 258 & 7.6 & 1.8 & 371 & 88 \\
\hline 400 & 0.3 & 2189 & 385 & 6.7 & 1.5 & 329 & 17 \\
\hline 800 & 0.3 & 1682 & 1310 & 4.3 & 2.5 & 361 & 97 \\
\hline 400 & 0.6 & 970 & 221 & 4.1 & 0.9 & 240 & 34 \\
\hline 800 & 0.6 & 1170 & 662 & 3.7 & 1.7 & 305 & 52 \\
\hline
\end{tabular}

Values denote mean ( $\pm S D, N=3$ ) over the steady state period of the experiment.

TABLE 2 | Overview of the two-way ANOVA results showing impacts of $p \mathrm{CO}_{2}$, growth rate and their interaction on host cellular C:P ratios, EOP, infective production rate, and infective burst size.

\begin{tabular}{|c|c|c|c|c|c|c|c|c|c|}
\hline \multirow[t]{2}{*}{ Data } & \multicolumn{3}{|c|}{$\mathrm{pCO}_{2}$} & \multicolumn{3}{|c|}{ Growth rate } & \multicolumn{3}{|c|}{ Interaction } \\
\hline & df & $\boldsymbol{F}$ & $P$ & df & $\boldsymbol{F}$ & $\boldsymbol{P}$ & df & $F$ & $P$ \\
\hline Cellular C:P ratio & 1 & 16.66 & 0.002 & 2 & 4.60 & 0.033 & 2 & 5.69 & 0.018 \\
\hline EOP & 1 & 64.46 & $<0.001$ & 2 & 32.54 & $<0.001$ & 2 & 81.12 & $<0.001$ \\
\hline $\begin{array}{l}\text { Infective production } \\
\text { rate }^{a}\end{array}$ & 1 & 4.45 & 0.057 & 2 & 46.86 & $<0.001$ & 2 & 7.78 & $<0.001$ \\
\hline Infective burst size & 1 & 20.99 & 0.001 & 2 & 46.25 & $<0.001$ & 2 & 17.33 & $<0.001$ \\
\hline
\end{tabular}

${ }^{a}$ Data were Ln-transformed to improve equality of variance. 


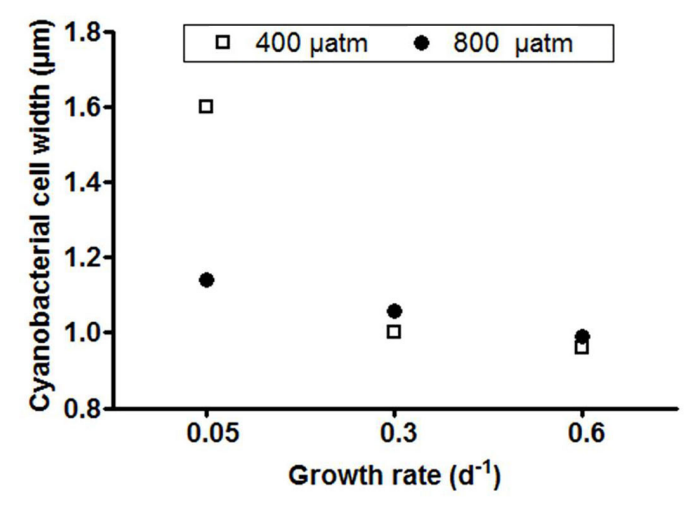

FIGURE 2 | Host cell width for each treatment. Symbols represent means of 20 cell measurements from one thin section for each chemostat.

The infection assays showed clear effects of host growth rate, and thereby the degree of P-limitation, as well as $\mathrm{pCO}_{2}$ on the various cyanophage infection characteristics (Supplementary Table 1). The adsorption (\% viral particles adsorbed to the host cells after $60 \mathrm{~min}$ ) at ambient $p \mathrm{CO}_{2}$ doubled with a decrease in growth and thereby an increasing strength of P-limitation (from 0.6 to $0.3 \mathrm{~d}^{-1}$; Figure $3 \mathrm{~A}$ ). Under elevated $\mathrm{pCO}_{2}$ conditions, the relatively low adsorption at high host growth rate $\left(0.6 \mathrm{~d}^{-1}\right)$ increased as compared to the ambient $p \mathrm{CO}_{2}$ conditions. The EOP (\% cyanophages that lead to infection) at ambient $p \mathrm{CO}_{2}$ showed a distinct positive correlation with the extent of P-limitation (Figure 3B). This effect disappeared, however, at elevated $p \mathrm{CO}_{2}$. At low host growth rate $\left(0.05 \mathrm{~d}^{-1}\right)$ the decrease in response to elevated $\mathrm{pCO}_{2}$ was even $67 \%$. The abortion percentage (\% adsorbed cyanophages that did not lead to infection) at ambient $p \mathrm{CO}_{2}$ was lowest at most severe P-limitation (from 50\% at $0.05 \mathrm{~d}^{-1}$ as compared to $69 \%$ at $0.3 \mathrm{~d}^{-1}$; Figure $3 \mathrm{C}$ ). Under elevated $p \mathrm{CO}_{2}$, abortion of PP increased strongly for the more severe P-limited treatments (from 50 to $89 \%$ at $0.05 \mathrm{~d}^{-1}$, and from 69 to $93 \%$ at $0.3 \mathrm{~d}^{-1} ; P<0.001$ ).

The latent period was strongly affected by the extent of P-limitation, i.e., the latent period was prolonged to $180-240 \mathrm{~min}$ at severe P-limitation, irrespective of the $\mathrm{pCO}_{2}$ condition (Figure 4). At the other P-limitation conditions, the latent period was $120-180 \mathrm{~min}$ at ambient $p \mathrm{CO}_{2}$. However, elevated $p \mathrm{CO}_{2}$ shortened the latent period to 60-120 $\mathrm{min}$ (Figure 4).

The infective production rate at ambient $\mathrm{pCO}_{2}$ decreased strongest with increasing P-limitation, i.e., it decreased by $62 \%$ from host growth rate 0.3 to $0.05 \mathrm{~d}^{-1}$ (Figure 5A). Elevated $p \mathrm{CO}_{2}$ caused a marked increase in infective production rate for the higher growth rate cultures, particularly for the cultures grown at $0.6 \mathrm{~d}^{-1}$ (from 0.16 to $0.54 \mathrm{~min}^{-1}$ ). The infective production rate was thus significantly influenced by both $\mathrm{pCO}_{2}$ and the extent of P-limitation, with both factors showing a clear interactive effect $(P<0.001$, Table 2$)$.

The trends of infective burst size with P-limitation and with $p \mathrm{CO}_{2}$ were largely comparable to the infective production rate. The lowest burst size was observed at the lowest growth rate with severe P-limitation (Figure 5B), while elevated $p \mathrm{CO}_{2}$ caused

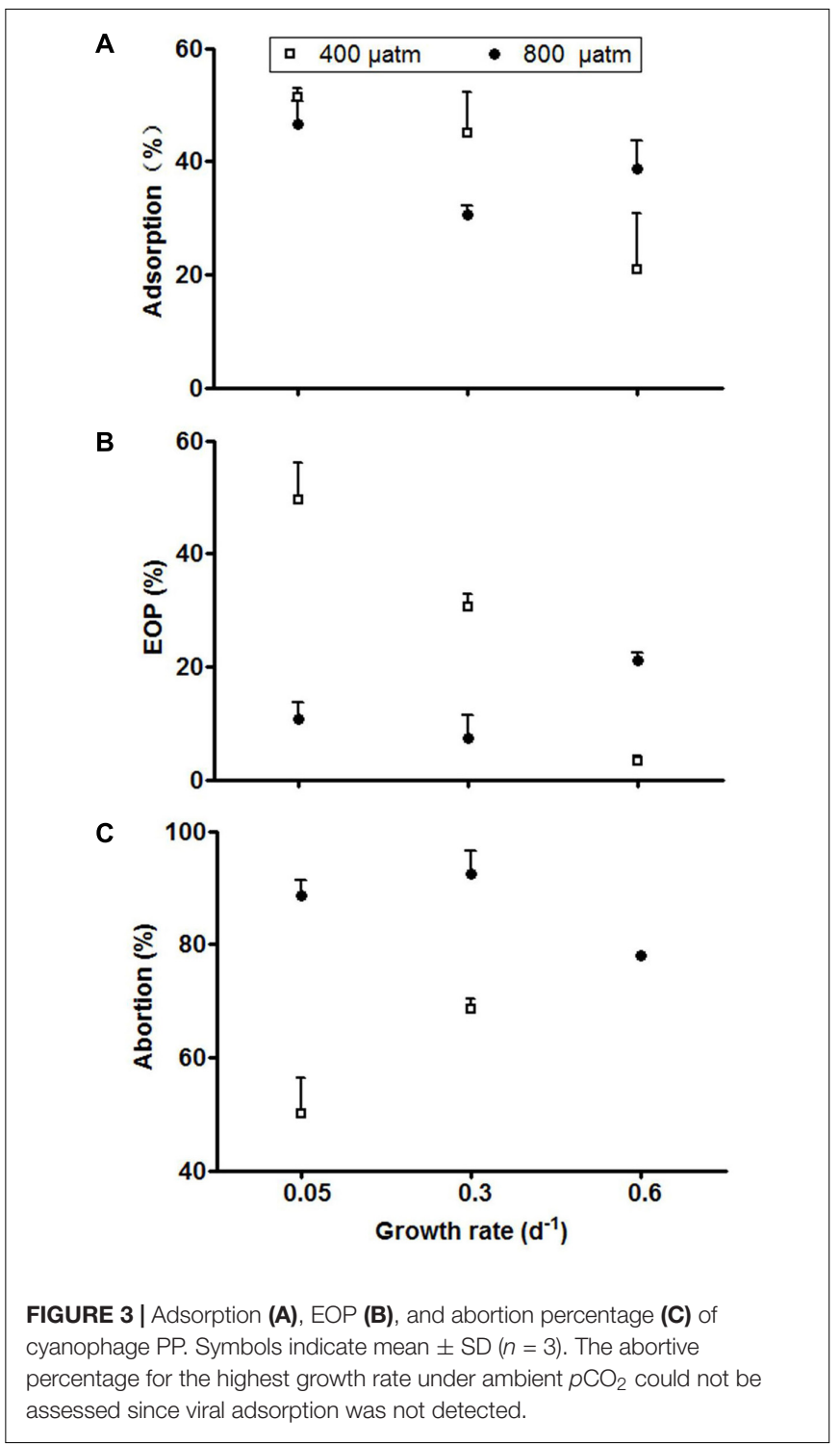

an increase in burst size at particularly the highest growth rate (from 23 to $35 \mathrm{PFU}$ cell ${ }^{-1}$; Figure 5B). The extent of P-limitation, elevated $p \mathrm{CO}_{2}$, as well as their interaction significantly affected virus burst size $(P<0.01$; Table 2$)$. In other words, the effect of $p \mathrm{CO}_{2}$ depended on the extent of P-limitation and seemed smallest under severe P-limitation (lowest growth rate) and largest at highest host growth rate $\left(0.6 \mathrm{~d}^{-1}\right)$.

\section{DISCUSSION}

\section{Host Status}

The observed C:P ratios of Phormidium at steady state were all distinctly higher as compared to the Redfield C:P ratio of 106, indicating that phosphorus limited growth (Table 1). This was furthermore confirmed by the residual phosphate concentrations in the chemostats that were all below detection limit (i.e., $<0.01 \mu \mathrm{M}$ ). The average cellular C:P ratios of 


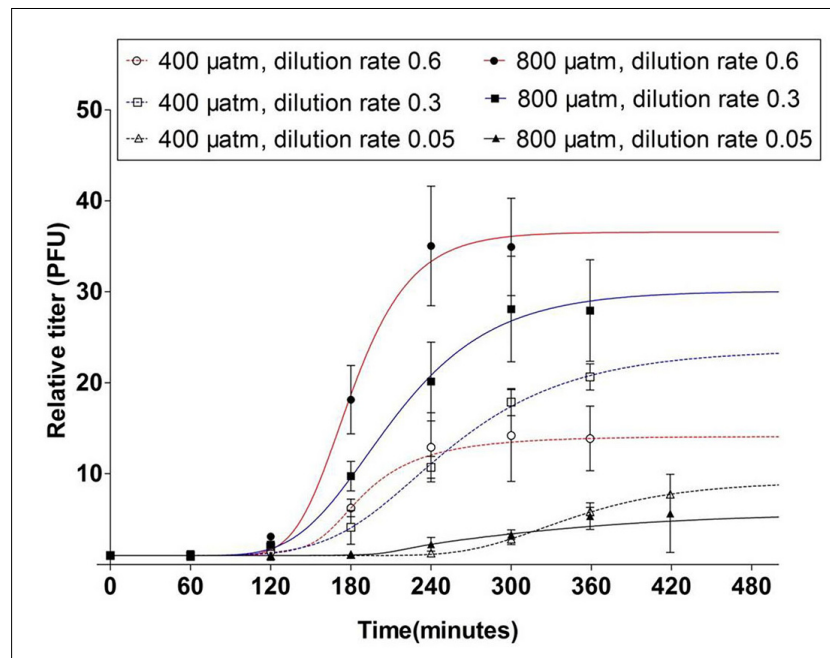

FIGURE 4 | One step growth curves of the cyanophage PP. Symbols indicate mean $\pm \operatorname{SD}(n=3)$. The relative titers are the cyanophage titers at each time point relative to those at $t_{0}$.
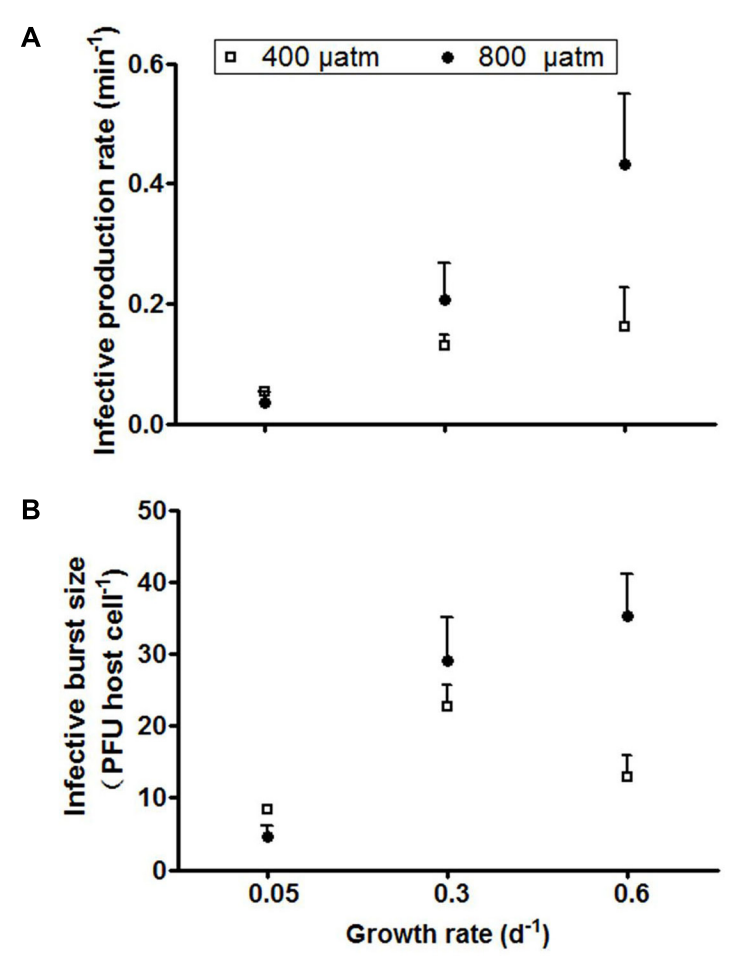

FIGURE 5 | Infective production rate (A) and infective burst size (B) of cyanophage PP. Symbols indicate mean $\pm \mathrm{SD}(n=3)$.

Phormidium significantly increased with P-limitation and even more so to $\mathrm{pCO}_{2}$ (Table 2). Cellular C:P ratios can be indicative for the extent by which cells are P-limited (Geider and LaRoche, 2002; Sterner and Elser, 2002), which is particularly evident for the displayed increase in C:P ratios from a growth rate of 0.6 to $0.3 \mathrm{~d}^{-1}$ (from 240 to 329 , and 305 to 361, for ambient and elevated $p \mathrm{CO}_{2}$, respectively). We note that $\mathrm{C}: \mathrm{P}$ ratios at ambient $p \mathrm{CO}_{2}$ and a growth rate of $0.05 \mathrm{~d}^{-1}$ were distinctly lower than observed in the other treatments (Table 1). This might be associated to the observed increase in cell size, where apparently POP is more strongly accumulated as compared to POC (Figure 2 and Table 1). Irrespective of growth rate, elevated $p \mathrm{CO}_{2}$ resulted in higher $\mathrm{C}: \mathrm{P}$ ratios of Phormidium. This may be due to continued fueling of the cells by $\mathrm{CO}_{2}$, while at the same time the lack of $\mathrm{P}$ supply (i.e., through the fixed dilution rates) made the C:P ratio even higher. Similarly, the C:P ratio increased with elevated $p \mathrm{CO}_{2}$ for Micromonas pusilla, and while the effect seemed stronger at lower growth rates (i.e., stronger P-limitation), no significant interaction between elevated $p \mathrm{CO}_{2}$ and P-limitation was observed (Maat et al., 2014).

\section{Virus Infection Experiments}

Generally, our results show that adsorption increased with the extent of P-limitation. More specifically, when Phormidium growth was severely P-limited $\left(0.05 \mathrm{~d}^{-1}\right.$, i.e., $17 \%$ of its maximum growth rate), adsorption of viruses was $51 \%$ as compared to $21 \%$ at the highest host growth rate $\left(0.6 \mathrm{~d}^{-1}\right.$, i.e., $83 \%$ of maximum growth rate). Little is known about the viral resistance mechanism of Phormidium, except that a $P$. uncinatum mutant strain was viral resistant due to the complete absence of viral adsorption (Bisen et al., 1986). Generally, adsorption of viruses depends on density (Murray and Jackson, 1992), as well as on host cell size, where larger host cells provide a greater surface area for contact (Hadas et al., 1997). In all adsorption assays, host and cyanophage abundances were kept similar and the observed differences can thus not be explained by changes in contact rate due to host density differences. However, Phormidium cells under the most severe P-limitation at $400 \mu$ atm $p \mathrm{CO}_{2}$ were overall $40 \%$ wider than in the other treatments, which may have contributed to an increased contact rate (Murray and Jackson, 1992).

Increased adsorption of viruses may also derive from enhanced production of extracellular polymeric substances (EPS) that is often observed under nutrient limitation or depletion (Zhao et al., 2014), as this serves as a sink for excess fixed cellular carbon under unbalanced carbon to nutrient stoichiometry (Otero and Vincenzini, 2004; Boonchai et al., 2015; GonzalezGarcia et al., 2015). However, the relatively high EOP and low abortion percentage at severe P-limitation and ambient $p \mathrm{CO}_{2}$ suggest that putatively higher EPS production does not prevent successful infection. Virus adsorption influences EOP, and the observed changes in adsorption ratio indeed correlated to those observed for EOP $(P<0.05)$. Thus, shifts in EOP could, at least partially, be explained by changes in adsorption ratio, with a higher adsorption leading to a higher EOP. Moreover, EOP increased significantly with elevated $\mathrm{pCO}_{2}(P<0.05)$ at the highest host growth rate. In contrast, elevated $p \mathrm{CO}_{2}$ at the lowest and intermediate host growth rates led to a strong decrease in EOP, which was associated to a concomitant increase in abortion percentage $(P<0.05)$. We hypothesize that under severe nutrient limited conditions excess carbon from photosynthesis cannot be allocated to growth because of a lack of nutrients, and may lead to the accumulation of EPS (Boonchai et al., 2015). This may subsequently result in a lower EOP by enhanced host 
TABLE 3 | Overview of responses of virus infection characteristics (latent period and burst size) to phytoplankton exposed to nutrient limitation or elevated $p \mathrm{CO}_{2}$.

\begin{tabular}{|c|c|c|c|c|c|c|c|c|}
\hline \multirow[t]{2}{*}{ Virus } & \multirow{2}{*}{$\begin{array}{l}\text { Hosts } \\
- \\
\text { Group }\end{array}$} & \multirow[b]{2}{*}{ Species } & \multirow[t]{2}{*}{ Habitat } & \multicolumn{2}{|c|}{ Nutrient limitation } & \multicolumn{2}{|c|}{$\mathrm{pCO}_{2}$ elevation } & \multirow[t]{2}{*}{ Reference } \\
\hline & & & & $\begin{array}{l}\text { Latent } \\
\text { period }\end{array}$ & $\begin{array}{l}\text { Burst } \\
\text { size }\end{array}$ & $\begin{array}{l}\text { Latent } \\
\text { period }\end{array}$ & $\begin{array}{l}\text { Burst } \\
\text { size }\end{array}$ & \\
\hline Cyanophage PP & C & Phormidium sp. & $\mathrm{F}$ & $\uparrow$ & $\downarrow$ & $\downarrow$ & $\uparrow$ & Present work \\
\hline Cyanophage PP & C & Phormidium sp. & $\mathrm{F}$ & $\uparrow$ & $\downarrow$ & NA & NA & Shang et al., 2016 \\
\hline Cyanophage PP & C & Plectonema boryanum IU597 & $\mathrm{F}$ & NA & NA & $\downarrow$ & $\downarrow$ & Cheng et al., 2017 \\
\hline Cyanophage PP & C & Leptolyngbya sp. & $\mathrm{F}$ & NA & NA & - & $\uparrow$ & Zhou et al., 2015 \\
\hline Cyanophage S-PM2 & C & Synechococcus sp. WH7803 & $\mathrm{M}$ & - & $\downarrow$ & NA & NA & Wilson et al., 1996 \\
\hline Cyanophage S-PM2 & C & Synechococcus sp. WH7803 & M & NA & NA & $\downarrow$ & $\downarrow$ & Traving et al., 2014 \\
\hline MpV-08T & $\mathrm{Ch}$ & Micromonas pusilla Lac38 & $\mathrm{M}$ & $\uparrow$ & $\downarrow$ & - & - & Maat et al., 2014 \\
\hline MpV-08T & Ch & Micromonas pusilla Lac38 & $M$ & $\uparrow$ & $\downarrow$ & NA & NA & $\begin{array}{l}\text { Maat and Brussaard, 2016; } \\
\text { Maat et al., 2016a,b }\end{array}$ \\
\hline PgV-07T & $\mathrm{H}$ & Phaeocystis globosa G(A) & $\mathrm{M}$ & $\uparrow$ & $\downarrow$ & NA & NA & $\begin{array}{l}\text { Maat and Brussaard, 2016; } \\
\text { Maat et al., 2016a }\end{array}$ \\
\hline PpV01 & $\mathrm{H}$ & Phaeocystis pouchetii & $M$ & NA & NA & - & - & Carreira et al., 2013 \\
\hline EhV-99B1 & $\mathrm{H}$ & Emiliania huxleyi BOF & $M$ & NA & NA & $\uparrow$ & $\uparrow$ & Carreira et al., 2013 \\
\hline
\end{tabular}

C, cyanobacteria; Ch, chlorophyta; $H$, haptophyta; F, freshwater; $M$, marine; $\uparrow$, increase; -, no impact; $\downarrow$, decrease; NA, not available.

resistance, possibly through trapping the phages in EPS and thereby preventing successful infection (Looijesteijn et al., 2001). Apparently, the potentially extra EPS production at elevated $p \mathrm{CO}_{2}$ did not affect the adsorption success. We recommend future studies to include EPS measurements to better understand the putative role of EPS in host resistance against virus infections.

P-limitation of Phormidium strongly reduced the propagation of infections, with a prolonged latent period, lowest infective production rate and infective burst size at severe P-limitation $\left(0.05 \mathrm{~d}^{-1}\right)$. These findings are comparable to other cyanophage and eukaryotic algae virus-host systems (Table 3). This suggests a more general negative effect of low $\mathrm{P}$ availability on virus infections, with an increased in latent period and a decrease in burst size with increasing P-limitation or under P depletion. The length of the latent period is mainly determined by synthesis of lysozymes, while burst size is mainly determined by the synthesis of proteins (Hadas et al., 1997). Thus, both factors depend on protein synthesis, for which the efficiency may possibly decrease with P-limitation through reduced cellular RNA content (Hessen et al., 2017). Alternatively, reduced photophosphorylation by the host as a consequence of P-limitation may possibly lead to depletion of energy reserves (Maat et al., 2016a), and as such limit cyanophage protein synthesis (Maat et al., 2016a; Puxty et al., 2018). Also, the observed negative effects of P-limitation on virus infectivity can possibly be explained by the high $\mathrm{P}$ demands of the viruses, as indicated by their generally low C:P ratio reflecting relatively high amounts of P-rich nucleic acids (Bratbak et al., 1993; Clasen and Elser, 2007).

Elevated $p \mathrm{CO}_{2}$ led to a shortened latent period of cyanophage $\mathrm{PP}$, an increased infective production rate, and an increase in infective burst size for the intermediate and fastest growing hosts. This enhanced cyanophage proliferation may result from a $\mathrm{CO}_{2}$-driven increase in net photosynthesis by the host, as suggested by the higher C:P ratios (Fu et al., 2007; Maat et al., 2017). An increased cyanophage burst size in response to elevated $\mathrm{pCO}_{2}$ was also observed for the nutrient replete filamentous cyanobacterium Leptolyngbya (Zhou et al., 2015), but not for Plectonema (Cheng et al., 2017) (Table 3). The latter study, however, did report a shortened latent period, alike we found. Elevated $p \mathrm{CO}_{2}$ also caused a decrease in latent period for a cyanophage infecting Synechococcus, though this was accompanied by a decrease in burst size (Traving et al., 2014). We note that Synechococcus is a unicellular marine cyanobacterium, while the other tested cyanobacterial hosts are freshwater filamentous species. Whether the growth strategy and habitat of cyanobacteria play a role in determining the responses of hosts toward phage infections under changing environmental conditions remains to be elucidated. The current lack of data on the effects of $p \mathrm{CO}_{2}$ on virus proliferation (including viruses infecting eukaryotic hosts), limits further generalizations.

Elevated $p \mathrm{CO}_{2}$ typically resulted in increased growth rate and biomass build-up of freshwater cyanobacteria species (Verspagen et al., 2014b; Cheng et al., 2017; Shi et al., 2017). As growth rate of hosts likely control phage production (Hadas et al., 1997), it is difficult to separate the direct $\mathrm{CO}_{2}$ impact from an indirect effect via $\mathrm{CO}_{2}$ induced changes in host growth rate when this is not well controlled [i.e., in batch experiments (Zhou et al., 2015)]. We show that under controlled host growth rates $\mathrm{CO}_{2}$ concentration alone could be directly responsible for differences in cyanophage infection and growth characteristics. Higher $p \mathrm{CO}_{2}$ can partly compensate for the metabolic constraints of P-limitation found to suppress cyanophage production, as long as the limitation is not too severe (i.e., not at the lowest host growth rates of $0.05 \mathrm{~d}^{-1}$ ).

Global environmental and climatic changes, such as shifts in nutrient supply and $p \mathrm{CO}_{2}$, affect the eco-physiology of cyanobacteria and thereby the formation of blooms (Visser et al., 2016; Huisman et al., 2018). Elevated $p \mathrm{CO}_{2}$ may promote cyanobacterial blooms, while associated warming may strengthen thermal stratification and subsequently nutrient limitation (O’Neil et al., 2012; De et al., 2013; Verspagen et al., 2014a; Xu et al., 2015). Although anthropogenic nutrient loading facilitates the development of harmful cyanobacterial blooms 
worldwide (Smith, 2003; Schindler, 2012; Paerl and Otten, 2013), inorganic carbon, light or nutrient limitation eventually causes bloom demise (Huisman et al., 2002; Verspagen et al., 2014b; Paerl et al., 2016). Phormidium can form dense blooms (Iwayama et al., 2017) but can also grow well under nutrient limiting conditions (this study; Fujimoto et al., 1997; Singh et al., 2014). Our findings demonstrate a combined effect of $p \mathrm{CO}_{2}$ and P-limitation on Phormidium and its phage, where the impact of elevated $p \mathrm{CO}_{2}$ on cyanophage PP growth characteristics depends on the extent of P-limitation. As such, the ecological impact of cyanophage infection will differ temporally (before, during, and post bloom) and between lakes with different trophic status.

Under moderate P-limitation, the enhanced cyanophage adsorption and production in combination with higher infective burst size at elevated $p \mathrm{CO}_{2}$ suggest an enhanced viral control of future Phormidium populations. Contrastingly, under severe P-limitation, the consistently lower cyanophage adsorption and EOP and higher abortion with elevated $p \mathrm{CO}_{2}$ demonstrates that higher $\mathrm{CO}_{2}$ levels greatly limit cyanophage PP infections and subsequently reduce viral control of Phormidium. In conclusion, we show that the combined effect of reduced $\mathrm{P}$ supply and elevated $\mathrm{pCO}_{2}$ as a result of global change will likely have a severe impact on virus growth characteristics and thereby on the control of harmful cyanobacterial hosts in freshwater ecosystems.

\section{REFERENCES}

Andersen, R. A. (2005). Algal Culturing Techniques. Oxford: Elsevier Ltd.

Battarbee, R. W., Anderson, N. J., Bennion, H., and Simpson, G. L. (2012). Combining limnological and palaeolimnological data to disentangle the effects of nutrient pollution and climate change on lake ecosystems: problems and potential. Freshw. Biol. 57, 2091-2106. doi: 10.1111/j.1365-2427.2012.02860.x

Behrenfeld, M. J., Worthington, K., Sherrell, R. M., Chavez, F. P., Strutton, P., Mcphaden, M., et al. (2006). Controls on tropical Pacific Ocean productivity revealed through nutrient stress diagnostics. Nature 442, 1025-1028. doi: 10. 1038/nature05083

Bisen, P. S., Audholia, S., Bhatnagar, A. K., and Bagchi, S. N. (1986). Evidence for lysogeny and viral resistance in the cyanobacterium Phormidium uncinatum. Curr. Microbiol. 13, 1-5. doi: 10.1007/BF01568150

Boatman, T. G., Lawson, T., and Geider, R. J. (2017). A Key marine diazotroph in a changing ocean: the interacting effects of temperature, $\mathrm{CO}_{2}$ and light on the growth of Trichodesmium erythraeum IMS101. PLoS One 12:e168796. doi: 10.1371/journal.pone.0168796

Boonchai, R., Kaewsuk, J., and Seo, G. (2015). Effect of nutrient starvation on nutrient uptake and extracellular polymeric substance for microalgae cultivation and separation. Desalin. Water Treat. 55, 360-367. doi: 10.1080/ 19443994.2014.939501

Boyce, D. G., Lewis, M. R., and Worm, B. (2011). Global phytoplankton decline over the past century. Nature 466, 591-596. doi: 10.1038/nature09268

Bratbak, G., Egge, J. K., and Heldal, M. (1993). Viral mortality of the marine alga Emiliania huxleyi (Haptophyceae) and termination of algal blooms. Mar. Ecol. Prog. Ser. 93, 39-48. doi: 10.3354/meps093039

Brussaard, C. P. D. (2004a). Optimization of procedures for counting viruses by flow cytometry. Appl. Environ. Microbiol. 70, 1506-1513. doi: 10.1128/AEM.70. 3.1506-1513.2004

Brussaard, C. P. D. (2004b). Viral control of phytoplankton populations-a review. J. Eukaryot. Microbiol. 51, 125-138. doi: 10.1111/j.1550-7408.2004.tb00537.x

Brussaard, C. P. D., Kuipers, B., and Veldhuis, M. J. W. (2005a). A mesocosm study of Phaeocystis globosa population dynamics: I. Regulatory role of viruses in bloom control. Harmful Algae 4, 859-874. doi: 10.1016/j.hal.2004.12.015

\section{AUTHOR CONTRIBUTIONS}

KC and TF did all the experiments. $\mathrm{CB}$ improved the quality of the manuscript. DVW designed the experiments and improved the manuscript.

\section{FUNDING}

This work was supported by the National Science Foundation of China (Grant Nos. 31200385, 51579092, and 91647207).

\section{ACKNOWLEDGMENTS}

We thank Jing Liu for help building the chemostats, Nico Helmsing for the elemental analyses, Suzanne Naus-Wiezer for the flow cytometry analyses, and Pei Zhang (from WHIOV) for the TEM work.

\section{SUPPLEMENTARY MATERIAL}

The Supplementary Material for this article can be found online at: https://www.frontiersin.org/articles/10.3389/fmicb. 2019.00617/full\#supplementary-material

Brussaard, C. P. D., Mari, X., Van Bleijswijk, J. D. L., and Veldhuis, M. J. W. (2005b). A mesocosm study of Phaeocystis globosa (Prymnesiophyceae) population dynamics: II. Significance for the microbial community. Harmful Algae 4, 875-893. doi: 10.1016/j.hal.2004.12.012

Carpenter, S. R., Kitchell, J. F., Cottingham, K. L., Schindler, D. E., Christense, D. L., Post, D. M., et al. (1996). Chlorophyll variability, nutrient input, and grazing: evidence from whole- lake experiments. Ecology 77, 725-735. doi: $10.2307 / 2265497$

Carreira, C. T., Heldal, M., and Bratbak, G. (2013). Effect of increased $\mathrm{pCO}_{2}$ on phytoplankton-virus interactions. Biogeochemistry 114, 391-397. doi: 10.1007/ s10533-011-9692-x

Chaturvedi, P., Kumar Agrawal, M., and Nath Bagchi, S. (2015). Microcystinproducing and non-producing cyanobacterial blooms collected from the Central India harbor potentially pathogenic Vibrio cholerae. Ecotox. Environ. Saf. 115, 67-74. doi: 10.1016/j.ecoenv.2015.02.001

Cheng, K., Van de Waal, D. B., Niu, X. Y., and Zhao, Y. J. (2017). Combined effects of elevated $\mathrm{pCO}_{2}$ and warming facilitate cyanophage infections. Front. Microbiol. 8:1096. doi: 10.3389/fmicb.2017.01096

Cheng, K., Zhao, Y. J., Du, X. L., Zhang, Y. R., Lan, S. B., and Shi, Z. L. (2007). Solar radiation-driven decay of cyanophage infectivity, and photoreactivation of the cyanophage by host cyanobacteria. Aquat. Microb. Ecol. 48, 13-18. doi: 10.3354/ame048013

Clasen, J. L., and Elser, J. J. (2007). The effect of host Chlorella NC64A carbon: phosphorus ratio on the production of Paramecium bursaria Chlorella Virus-1. Freshw. Biol. 52, 112-122. doi: 10.1111/j.1365-2427.2006.01677.x

De, S. D. L. N., Elser, J. J., Gsell, A. S., Huszar, V. L. M., Ibelings, B. W., Jeppesen, E., et al. (2013). Plankton dynamics under different climatic conditions in space and time. Freshw. Biol. 58, 463-482. doi: 10.1111/fwb.12053

Elser, J. J., Bracken, M. E., Cleland, E. E., Gruner, D. S., and Harpole, W. S. (2007). Global analysis of nitrogen and phosphorus limitation of primary producers in freshwater, marine and terrestrial ecosystems. Ecol. Lett. 10, 1135-1142. doi: 10.1111/j.1461-0248.2007.01113.x

Field, C. B., Behrenfeld, M. J., Randerson, J. T., and Falkowski, P. (1998). Primary production of the biosphere: integrating terrestrial and oceanic components. Science 282, 237-240. doi: 10.1126/science.281.5374.237 
Finkel, Z. V., Beardall, J., Flynn, K. J., Quigg, A., Rees, T. A. V., and Raven, J. A. (2010). Pytoplankton in a changing world: cell size and elemental stoichiometry. J. Plankton Res. 32, 119-137. doi: 10.1093/plankt/fbp098

Fox, J. A., Booth, S. J., and Martin, E. L. (1976). Cyanophage SM-2: a new bluegreen algal virus. Virology 73, 557-560. doi: 10.1016/0042-6822(76)90420-7

Frenken, T., Velthuis, M., Senerpont, D. L. N., Stephan, S., Aben, R., Kosten, S., et al. (2016). Warming accelerates termination of a phytoplankton spring bloom by fungal parasites. Glob. Change Biol. 22, 299-309. doi: 10.1111/gcb.13095

Friedlingstein, P., Andrew, R. M., Rogelj, J., Peters, J. P., and Canadell, J. G. (2014). Persistent growth of $\mathrm{CO}_{2}$ emissions and implications for reaching climate targets. Nat. Geosci. 7, 709-715. doi: 10.1038/ngeo2248

Fu, F. X., Warner, M. E., Zhang, Y., Feng, Y., and Hutchins, D. A. (2007). Effects of increased temperature and $\mathrm{CO}_{2}$ on photosynthesis, growth, and elemental ratios in marine Synechococcus and Prochlorococcus (Cyanobacteria). J. Phycol. 43, 485-496. doi: 10.1111/j.1529-8817.2007.00355.x

Fujimoto, N., Sudo, R., Sugiura, N., and Inamori, Y. (1997). Nutrient-limited growth of Microcystis aeruginosa and Phormidium tenue and competition under various N:P supply ratios and temperatures. Limnol. Oceanogr. 42, 250-256. doi: 10.4319/lo.1997.42.2.0250

Garcia, N. S., Fu, F. X., Breene, C. L., Bernhardt, P. W., and Mulholland, M. R. (2011). Interactive effects of irradiance and $\mathrm{CO}_{2}$ on $\mathrm{CO}_{2}$ fixation and $\mathrm{N}_{2}$ fixation in the Diazotroph Trichodesmium erythraeum (cyanobacteria). J. Phycol. 47, 1292-1303. doi: 10.1111/j.1529-8817.2011.01078.x

Geider, R. J., and LaRoche, J. L. (2002). Redfield revisited: variability of C:N:P in marine microalgae and its biochemical basis. Eur. J. Phycol. 37, 1-17. doi: $10.1017 /$ S0967026201003456

Gobler, C. J., Hutchins, D. A., Fisher, N. S., Cosper, E. M., and Saòdo-Wilhelmy, S. A. (1997). Release and bioavailability of C, N, P Se, and Fe following viral lysis of a marine chrysophyte. Limnol. Oceanogr. 42, 1492-1504. doi: 10.4319/ lo.1997.42.7.1492

Gonzalez-Garcia, Y., Heredia, A., Carlos Meza-Contreras, J., Escalante, F. M. E., Maria Camacho-Ruiz, R., and Cordova, J. (2015). Biosynthesis of extracellular polymeric substances by the marine bacterium Saccharophagus degradans under different nutritional conditions. Int. J. Polym. Sci. 2015:526819. doi: $10.1155 / 2015 / 526819$

Hadas, H., Einav, M., Fishov, I., and Zaritsky, A. (1997). Bacteriophage T4 development depends on the physiology of its host Escherichia coli. Microbiology 143, 179-185. doi: 10.1099/00221287-143-1-179

Hessen, D. O., Hafslund, O. T., Andersen, T., Broch, C., Shala, N. K., and Wojewodzic, M. W. (2017). Changes in stoichiometry, cellular rna, and alkaline phosphatase activity of Chlamydomonas in response to temperature and nutrients. Front. Microbiol. 8:18. doi: 10.3389/fmicb.2017.00018

Huisman, J., Codd, G. A., Paerl, H. W., Ibelings, B. W., Verspagen, J. M. H., and Visser, P. M. (2018). Cyanobacterial blooms. Nat. Rev. Microb. 16, 471-483. doi: 10.1038/s41579-018-0040-1

Huisman, J., Matthijs, H. C., Visser, P. M., Balke, H., Sigon, C. A., Passarge, J., et al. (2002). Principles of the light-limited chemostat: theory and ecological applications. Antonie Van Leeuwenhoek 81, 117-133. doi: 10.1023/A: 1020537928216

Iwayama, A., Ogura, H., Hirama, Y., Chang, C. W., Hsieh, C. H., and Kagami, M. (2017). Phytoplankton species abundance in Lake Inba (Japan) from 1986 to 2016. Ecol. Res. 32, 783-783. doi: 10.1007/s11284-017-1482-Z

Jenkins, C. A., and Hayes, P. K. (2006). Diversity of cyanophages infecting the heterocystous filamentous cyanobacterium Nodularia isolated from the brackish Baltic Sea. J. Mar. Biol. Assoc. U. K. 86, 529-536. doi: 10.1017/ s0025315406013439

Jover, L. F., Effler, T. C., Buchan, A., Wilhelm, S. W., and Weitz, J. S. (2014). The elemental composition of virus particles: implications for marine biogeochemical cycles. Nat. Rev. Microb. 12, 519-528. doi: 10.1038/ nrmicro3289

Liu, X., Kong, S., Shi, M., Fu, L. W., Gao, Y., and An, C. C. (2008). Genomic analysis of freshwater cyanophage $\mathrm{Pf}_{-} \mathrm{WMP}_{3}$ infecting cyanobacterium Phormidium foveolarum: the conserved elements for a phage. Microb. Ecol. 56, 671-680. doi: 10.1007/s00248-008-9386-7

Liu, X., Shi, M., Kong, S., Gao, Y., and An, C. C. (2007). Cyanophage PfWMP4, a T7-like phage infecting the freshwater cyanobacterium Phormidium foveolarum: complete genome sequence and DNA translocation. Virology 366, 28-39. doi: 10.1016/j.virol.2007.04.019
Looijesteijn, P. J., Trapet, L., De, V. E., Abee, T., and Hugenholtz, J. (2001). Physiological function of exopolysaccharides produced by Lactococcus lactis. Int. J. Food Microb. 64, 71-80. doi: 10.1016/S0168-1605(00)00437-2

Maat, D. S., Biggs, T., Evans, C., van Bleijswijk, J. D. L., van der Wel, N. N., Dutilh, B. E., et al. (2017). Characterization and temperature dependence of Arctic Micromonas polaris viruses. Viruses 9:134. doi: 10.3390/v9060134

Maat, D. S., Blok, R. D., and Brussaard, C. P. D. (2016a). Combined phosphorus limitation and light stress prevent viral proliferation in the phytoplankton species Phaeocystis globosa, but not in Micromonas pusilla. Front. Mar. Sci. 3:160. doi: 10.3389/fmars.2016.00160

Maat, D. S., van Bleijswijk, J. D. L., Witte, H. J., and Brussaard, C. P. D. (2016b). Virus production in phosphorus-limited Micromonas pusilla stimulated by a supply of naturally low concentrations of different phosphorus sources, far into the lytic cycle. FEMS Microb. Ecol. 92:fiw136. doi: 10.1093/femsec/fiw136

Maat, D. S., and Brussaard, C. P. D. (2016). Both phosphorus- and nitrogen limitation constrain viral proliferation in marine phytoplankton. Aquat. Microb. Ecol. 77, 87-97. doi: 10.3354/ame01791

Maat, D. S., Crawfurd, K. J., Timmermans, K. R., and Brussaard, C. P. D. (2014). Elevated $\mathrm{CO}_{2}$ and phosphate limitation favor Micromonas pusilla through stimulated growth and reduced viral impact. Appl. Environ. Microbiol. 80, 3119-3127. doi: 10.1128/aem.03639-13

Marie, D., Partensky, F., Vaulot, D., and Brussaard, C. P. D. (2001). Enumeration of phytoplankton, bacteria, and viruses in marine samples. Curr. Protoc. Cytom. 11, 1-15. doi: 10.1002/0471142956.cy1111s10

McAllister, T. G., Wood, S. A., and Hawes, I. (2016). The rise of toxic benthic Phormidium proliferations: a review of their taxonomy, distribution, toxin content and factors regulating prevalence and increased severity. Harmful Algae 55, 282-294. doi: 10.1016/j.hal.2016.04.002

Mojica, K. D. A., and Brussaard, C. P. D. (2014). Factors affecting virus dynamics and microbial host-virus interactions in marine environments. FEMS Microbiol. Ecol. 89, 495-515. doi: 10.1111/1574-6941.12343

Mojica, K. D. A., Evans, C., and Brussaard, C. P. D. (2014). Flow cytometric enumeration of marine viral populations at low abundances. Aquat. Microb. Ecol. 71, 203-209. doi: 10.3354/ame01672

Mojica, K. D. A., Huisman, J., Wilhelm, S. W., and Brussaard, C. P. D. (2016). Latitudinal variation in virus-induced mortality of phytoplankton across the North Atlantic Ocean. ISME J. 10, 500-513. doi: 10.1038/ismej.2015.130

Mou, S., Zhang, Y., Li, G., Li, H. M., Liang, Y. T., Tang, L. L., et al. (2017). Effects of elevated $\mathrm{CO}_{2}$ and nitrogen supply on the growth and photosynthetic physiology of a marine cyanobacterium, Synechococcus sp. PCC7002. J. Appl. Phycol. 29, 1755-1763. doi: 10.1007/s10811-017-1089-3

Murray, A. G., and Jackson, G. A. (1992). Viral dynamics: a model of the effects of size,shape, motion and abundance of single-celled planktonic organisms and other particles. Mar. Ecol. Prog. Ser. 89, 103-116. doi: 10.3354/meps089103

O'Neil, J. M., Davis, T. W., Burford, M. A., and Gobler, C. J. (2012). The rise of harmful cyanobacteria blooms: the potential roles of eutrophication and climate change. Harmful Algae 14, 313-334. doi: 10.1016/j.hal.2011.10.027

Otero, A., and Vincenzini, M. (2004). Nostoc (Cyanophyceae) goes nude: extracellular polysaccharides serve as a sink for reducing power under unbalanced C/N metabolism. J. Phycol. 40, 74-81. doi: 10.1111/j.0022-3646. 2003.03-067.x

Paerl, H. W., and Otten, T. G. (2013). Harmful cyanobacterial blooms: causes, consequences, and controls. Microb. Ecol. 65, 995-1010. doi: 10.1007/s00248012-0159-y

Paerl, H. W., Scott, J. T., McCarthy, M. J., Newell, S. E., Gardner, W. S., Havens, K. E., et al. (2016). It takes two to tango: when and where dual nutrient (N \& $\mathrm{P})$ reductions are needed to protect lakes and downstream ecosystems. Environ. Sci. Technol. 50, 10805-10813. doi: 10.1021/acs.est.6b02575

Puxty, R. J., Evans, D. J., Millard, A. D., and Scanlan, D. J. (2018). Energy limitation of cyanophage development: implications for marine carbon cycling. ISME J. 12, 1273-1286. doi: 10.1038/s41396-017-0043-3

Safferman, R. S., and Morris, M. E. (1963). Algal virus: isolation. Science 140, 679-680. doi: 10.1126/science.140.3567.679

Schindler, D. W. (2012). The dilemma of controlling cultural eutrophication of lakes. Proc. Biol. Sci. 279, 4322-4333. doi: 10.1098/rspb.2012.1032

Shang, S. Y., Ma, H., Zhao, Y. J., and Cheng, K. (2016). Effect of nutrient status on the kinetics of cyanophage PP infection in Phormidium. Ying Yong Sheng Tai Xue Bao 27, 1271-1276. doi: 10.13287/j.1001-9332.201604.028 
Shi, X., Li, S., Wei, L., Qin, B. Q., and Brookes, J. D. (2017). $\mathrm{CO}_{2}$ alters community composition of freshwater phytoplankton: a microcosm experiment. Sci. Total Environ. 607, 69-77. doi: 10.1016/j.scitotenv.2017.06.224

Sinang, S. C., Poh, K. B., Shamsudin, S., and Sinden, A. (2015). Preliminary assessment of cyanobacteria diversity and toxic potential in ten freshwater lakes in Selangor, Malaysia. Bull. Environ. Contam. Tox. 95, 542-547. doi: 10.1007/ s00128-015-1620-7

Singh, Y., Khattar, J. I. S., Singh, D. P., Rahi, P., and Gulati, A. (2014). Limnology and cyanobacterial diversity of high altitude lakes of lahaul-spiti in himachal pradesh, India. J. Biosci. 39, 643-657. doi: 10.1007/s12038-014-9458-4

Smith, V. H. (2003). Eutrophication of freshwater and coastal marine ecosystems: a global problem. Environ. Sci. Pollut. Res. 10, 126-139. doi: 10.1065/espr2002. 12.142

Srivastava, A., Ahn, C. Y., Asthana, R. K., Lee, H. G., and Oh, H. M. (2015). Status, alert system, and prediction of cyanobacterial bloom in south korea. Biomed. Res. Int. 2015:584696. doi: 10.1155/2015/584696

Steenhauer, L. M., Wierenga, J., Carreira, C., Limpens, R. W. A. L., Koster, A. J., and Pollard, P. C. (2016). Isolation of cyanophage CrV infecting Cylindrospermopsis raciborskii and the influence of temperature and irradiance on CrV proliferation. Aquat. Microb. Ecol. 78, 11-23. doi: 10.3354/ame 01800

Sterner, R. W., and Elser, J. J. (2002). Ecological Stoichiometry: The Biology of Elements from Molecules to the Biosphere. Princeton: Princeton University Press.

Stocker, T., Qin, D. H., Plattner, G. K., Tignor, M. M. B., Allen, S. K., Boschung, J., et al. (2013). Climate Change 2013: The Physical Science Basis: Summary for Policymakers. Switzerland: IPCC.

Suttle, C. A. (1993). "Enumeration and isolation of viruses," in Handbook of Method in Aquatic Microbial Ecology, ed. P. F. Kemp (Boca Raton FL: Lewis Publishers), 121-134.

Suttle, C. A. (2007). Marine viruses - major players in the global ecosystem. Nat. Rev. Microbiol. 5, 801-812. doi: 10.1038/nrmicro 1750

Tijdens, M., van de Waal, D. B., Slovackova, H., Hoogveld, H. L., and Gons, H. J. (2008). Estimates of bacterial and phytoplankton mortality caused by viral lysis and microzooplankton grazing in a shallow eutrophic lake. Freshw. Biol. 53, 1126-1141. doi: 10.1111/j.1365-2427.2008.01958.x

Traving, S. J., Clokie, M. R. J., and Middelboe, M. (2014). Increased acidification has a profound effect on the interactions between the cyanobacterium Synechococcus sp. WH7803 and its viruses. FEMS Microb. Ecol. 87, 133-141. doi: 10.1111/1574-6941.12199

Van de Waal, D. B., Verschoor, A. M., Verspagen, J. M. H., Van Donk, E., and Huisman, J. (2010). Climate-driven changes in the ecological stoichiometry of aquatic ecosystems. Front. Ecol. Environ. 8, 145-152. doi: 10.1890/ 080178

Verspagen, J. M. H., Van de Waal, D. B., Finke, J. F., Visser, P. M., and Huisman, J. (2014a). Contrasting effects of rising $\mathrm{CO}_{2}$ on primary production and ecological stoichiometry at different nutrient levels. Ecol. Lett. 17, 951-960. doi: 10.1111/ ele. 12298

Verspagen, J. M. H., Van de Waal, D. B., Finke, J. F., Visser, P. M., Van Donk, E., and Huisman, J. (2014b). Rising $\mathrm{CO}_{2}$ levels will intensify phytoplankton blooms in eutrophic and hypertrophic lakes. PLoS One 9:e104325. doi: 10.1371/journal. pone. 0104325
Visser, P. M., Verspagen, J. M. H., Sandrini, G., Stal, L. J., Matthijs, H. C. P., and Davis, T. W. (2016). How rising $\mathrm{CO}_{2}$ and global warming may stimulate harmful cyanobacterial blooms. Harmful Algae 54, 145-159. doi: 10.1016/j.hal. 2015.12.006

Wigington, C. H., Sonderegger, D., Brussaard, C. P. D., Buchan, A., Finke, J. F., Fuhrman, J. A., et al. (2016). Re-examination of the relationship between marine virus and microbial cell abundances. Nat. Microb. 1:15024. doi: 10.1038/ nmicrobiol.2015.24

Wilson, W. H., Carr, N. G., and Mann, N. H. (1996). The effect of phosphate status on the kinetics of cyanophage infection in the oceanic cyanobacterium Synechococcus sp. WH7803. J. Phycol. 32, 506-516. doi: 10.1111/j.0022-3646. 1996.00506.x

Wood, S. A., Puddick, J., Fleming, R., and Heussner, A. H. (2017). Detection of anatoxin-producing Phormidium in a New Zealand farm pond and an associated dog death. New Zeal. J. Bot. 55, 36-46. doi: 10.1080/0028825X.2016. 1231122

Xu, H., Paerl, H. W., Qin, B., Zhu, G., Hall, N. S., and Wu, Y. (2015). Determining critical nutrient thresholds needed to control harmful cyanobacterial blooms in eutrophic Lake Taihu, China. Environ. Sci. Technol. 49, 1051-1059. doi: 10.1021/es503744q

Xu, H., Paerl, H. W., Qin, B., Zhu, G. W., and Gao, G. A. (2010). Nitrogen and phosphorus inputs control phytoplankton growth in eutrophic Lake Taihu, China. Limnol. Oceanogr. 55, 420-432. doi: 10.4319/lo.2010.55.1.0420

Zhao, B., Jiang, Y., Jin, Y., and Zhang, J. B. (2014). Function of bacterial cells and their exuded extracellular polymeric substances (EPS) in virus removal by red soils. Environ. Sci. Pol. Res. Int. 21, 9242-9250. doi: 10.1007/s11356-014-2829-4

Zhao, Y. J., Cheng, K., Shi, Z. L., Guo, Y. X., Zhu, H. Y., Zhang, J. H., et al. (2002). Isolation and identification of the first cyanophage in China. Prog. Nat. Sci. 12, 923-927.

Zhou, Q., Gao, Y., Zhao, Y. J., and Cheng, K. (2015). The effect of elevated carbon dioxide concentration on cyanophage PP multiplication and photoreactivation induced by a wild host cyanobacterium. Acta Ecol. Sin. 35, 11-15. doi: 10.1016/ j.chnaes.2014.11.001

Zhou, Q., Zhou, F., Liao, M., Zhao, Y., and Cheng, K. (2010). The photoreactivation ratio of cyanophage $\mathrm{PP}$ in wild host under different light or temperature conditions. Acta Ecol. Sin. 30, 1868-1874.

Zwietering, M. H., Jongenburger, I., Rombouts, F. M., and van 't Riet, K. (1990). Modeling of the bacterial growth curve. Appl. Environ. Microbiol. 56, 1875-1881.

Conflict of Interest Statement: The authors declare that the research was conducted in the absence of any commercial or financial relationships that could be construed as a potential conflict of interest.

Copyright (c) 2019 Cheng, Frenken, Brussaard and Van de Waal. This is an openaccess article distributed under the terms of the Creative Commons Attribution License (CC BY). The use, distribution or reproduction in other forums is permitted, provided the original author(s) and the copyright owner(s) are credited and that the original publication in this journal is cited, in accordance with accepted academic practice. No use, distribution or reproduction is permitted which does not comply with these terms. 